at a height of four inches they developed the symptoms of kromnek and became 100 per cent infected, growth immediately coming to a standstill. An outstanding contrast was offered by the sprayed beds, which showed vigorous healthy growth, not more than 5 per cent of the plants becoming diseased. Those left in the beds after thinning yielded a bountiful crop.

Spraying of transplanted tomatoes gave promising results, in view of the very small scale of the tests and of the consequent continuous invasion of insects from the unsprayed rows to the trial rows adjoining.

$$
\text { E. S. Moore. }
$$

The Laboratory,

Balfour, Cape Province, South Africa.

Feb. 13.

'Moore, E. S., Science Bull. 123, Dept. Agric. Union of South Africa (1933).

${ }^{2}$ Moore, E. S., and Anderssen, E. E., Science Bull, 182, Dept. Agric. Union of South Africa (1939).

"Hean, A. F., "Kromnek in South Africa", Farming in South Africa (October 1940).

\section{Inactivation of the Causative Agent of Fowl-Leukosis by X-Rays}

THE following is a report on the inactivation of the causative agent of fowl leucosis (hæmacytoblastosis, Strain $T$ Engelbreth-Holm) by means of X-rays.

The method used was as follows: blood was withdrawn from the animal at the height of the infection, with the addition of sodium citrate. A drop of this blood was placed on a concave slide, covered with a mica coverslip $0.03 \mathrm{~mm}$. thick and made air-tight with paraffin. Blood drops mounted in this way were irradiated. After irradiation every drop was diluted with 2 c.c. of Ringer's solution, and 1 c.c. of the diluted blood was inoculated intravenously into a fowl. Altogether six series of experiments were carried out on thirty-four fowls. Control experiments were made for each series with non-irradiated blood.

Irradiation was carried out by means of a demountable X-ray tube with copper anode operated on a vacuum pump at a tension of $35 \mathrm{kv}$. and a current of $30 \mathrm{ma}$. The intensity of the X-rays was about $105,000 \mathrm{r} . / \mathrm{min}$. at the distance of the irradiated sub. ject. According to absorption analysis the overwhelming part of the radiation used consisted in characteristic $K$-rays of the anode material (copper). The half-value layer in aluminium was $0.053 \mathrm{~mm}$. The results are given in the accompanying table. Leucotic virus is destroyed with certainty by a

\begin{tabular}{|c|c|c|c|}
\hline $\begin{array}{c}\text { X-ray dose } \\
\text { in million r. }\end{array}$ & $\begin{array}{c}\text { No, of chicks } \\
\text { injected }\end{array}$ & $\begin{array}{c}\text { Successful } \\
\text { injections }\end{array}$ & $\begin{array}{c}\text { Unsuccessful } \\
\text { injections }\end{array}$ \\
\cline { 1 - 2 } & 2 & 2 & 0 \\
\hline$\frac{1}{2}$ & 2 & 2 & 0 \\
2 & 4 & 4 & 0 \\
3 & 5 & $2 *$ & 3 \\
4 & 11 & 0 & 11 \\
5 & 6 & 0 & 6 \\
6 & 4 & 0 & 4 \\
\hline
\end{tabular}

* Anæmic forms. dose of $4,000,000$ r.; $2,000,000$ r. has no effect. When $3,000,000 \mathrm{r}$. is used results vary. We obtained three negative results against two takes; both the latter showed an anæmic form of hæmacytoblastosis.

The doses used by us for inactivating the agent of fowl leukosis lie in the same range as those used for inactivating the few viruses of which the resistance to irradiation has been determined. The inactivating dose for fowl plague virus is $3,000,000 \mathrm{r}$. (Levin and Lominski ${ }^{1}$ ), for infectious papilloma of the rabbit $3,000,000$ r. (Lacassagne and $N y \theta^{2}$ ), for vaccinia somewhat more than $3,900,000 \mathrm{r}$. (Gowen and Lucas ${ }^{3}$ ). The doses used by us for inactivation are many times larger than those employed hitherto in attempts to influence the leucotic agent, and this is undoubtedly the reason for the negative results obtained by Engelbreth-Holm and Rothe-Meyer ${ }^{4}$, by Forfota ${ }^{5}$ and by Jarmai ${ }^{6}$.

This work has been aided by a grant from the Lady Tata Memorial Trust.

\section{DOLJANSKI. \\ G. GoldhaBer. \\ M. Prkovski.}

Department of Experimental Pathology and the Radiological Department (Cancer Laboratories),

Hebrew University, Jerusalem. Feb. 2.

'Levin, B., and Lominski, I., C.R., 208, 350 (1936).

2 Lacassagne, A., and Nyke, W., C.R. Soc. Biol., 128, 1038 (1938).

s Gowen, J. W., and Lucas, A. M., Science, 90, 621 (1939).

- Engelbreth-Holm, J., and Rothe-Meyer, A., Acta path. et microbiol. scand., 9, 293 (1932).

s Forfota, E., Strahlenther., 59, 83 (1937).

'Jarmai, K., Arch. wiss. u. prakt. Tierheilk., 74, 67 (1939).

\section{Diffuse X-Ray Reflexions}

Following the observation by Sir William Bragg that diffuse scattering takes the form which it should have if it were due to diffraction by small groups of atoms within a crystal (as originally suggested by Preston), Prof. G. E. M. Jauncey ${ }^{1}$ has obtained a formula giving the resulting positions of the diffuse spots for small values of $\left(i-i_{B}\right), i$ being the glancing angle of incidence on the set of crystal planes for which $i_{B}$ is the Bragg angle. He expresses astonishment that this formula is identical with those deduced by Zachariasen and by Raman and Nath, each on very different assumptions. Mr. G. D. Preston ${ }^{2}$ has pointed out that this formula is an approximation to the formula given by Faxén in 1923, and stated that the physical interpretation of Faxén's formula is that the surfaces of constant intensity surrounding the Bragg points are spheres. This, however, is again only true when $\left(i-i_{B}\right)$ is small.

The reason why all these different assumptions (for example, existence of small groups, waves of the Raman type or elastic heat waves) give the same formula for small values of $\left(i-i_{B}\right)$ is that in the derivation of each formula it is implicitly or explicitly assumed that the spreading of the intensity of reflecting power around each reciprocal lattice point is independent of direction. Consequently, the formulæ are simply a geometrical way of expressing 